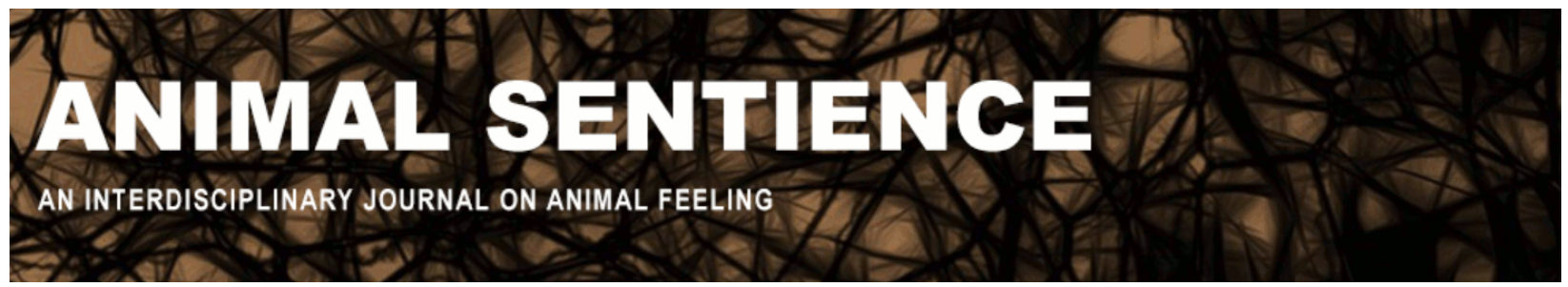

Figueroa, Daniela and Duprat, Ximena (2020) Remedying anthropogenic zoonoses. Animal Sentience 30(29)

DOI: $10.51291 / 2377-7478.1666$

Date of submission: 2021-01-04

Date of acceptance: 2021-01-04 (c) 


\title{
Remedying anthropogenic zoonoses
}

Commentary on Wiebers \& Feigin on Covid Crisis

\author{
Daniela Patricia Figueroa ${ }^{1} \&{\text { Ximena } \text { Duprat }^{2}}^{2}$ \\ ${ }^{1}$ Adolfo Ibañez University. \\ ${ }^{2}$ Ibero \& The Caribbean Network.
}

\begin{abstract}
Zoonotic diseases represent $60 \%$ of the infections suffered by the human species. in light of the latest episodes of epidemics and pandemics we have to begin to address health problems with another perspective. The "One Health" vision aims to generate a change in consciousness and a new working strategy.
\end{abstract}

Daniela Figueroa, veterinarian and researcher in the Ecophysiological Modeling Lab, Adolfo Ibáñez University is Founder of One Health Latin America and President of Education and Science Foundation. Website.

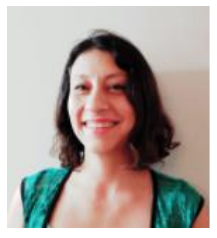

Ximena Duprat, veterinarian, is Education Coordinator at the One Health Latin America and Executive Director of Applied Research Center of Chile. Website

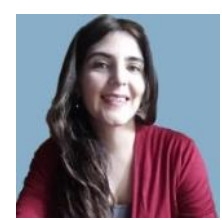

Human history has faced countless pandemics, from the Black Death in the 14th century and the Spanish flu in the early 19th century, to SARS Cov-2 today. Have we learned from our history? Probably, but despite advances in science and technology, our "cognitively superior" species, expanding and colonizing unprecedented places, has not yet been unable to prevent the scourges from infectious agents resulting from our own activity.

Emerging zoonotic diseases represent a growing threat, being the cause of $60 \%$ of the infectious diseases afflicting our species (Taylor et al. 2001; Jones et al. 2008). "Reservoirs" in the form of rodents, bats and birds play an intermediary role as pest controllers, pollinators, and seed diffusers (FAO, 2020) or as food for other animals. Infectious diseases in wild ecosystems are a point of equilibrium; diseases adjust their size and are later compensated by growth cycles (Rodriguez, 2013).

We can cite an endless number of causes of zoonoses but the main one has been our anthropocentrism and egocentrism (Chapman \& Huffman 2018): the human is the center of the world and the human desire to expand and excel economically does not reckon the consequences. According to evolutionists like E. O. Wilson and Niles Eldredge, there is evidence that humans are now causing the "Sixth Mass Extinction" (Pievani, 2014). A prominent example of anthropogenic effects is the ozone hole over Antarctica; it shows that human activity can have 
a negative effect on a broad range of ecosystem services that support human life (Steffen et. al, 2011).

There is a lack of communication between the scientific world and civil society. Public attitudes to science depend on the social role accorded to it. Science can, of course, be exploited for many good causes, conventionally designated by expressions such as 'wealth creation', 'international competitiveness', 'national security', 'public health', 'social welfare', etc. (Ziman, 2003). But education must provide scientific literacy to society, encouraging critical thinking in when facing events like pandemics. To devise measures to curb the health impact of a disease like SARS Cov-2 it is important to understand the causal factors. The infectious cycle needs to be understood. Direct person-to-person transmission can be inhibited by proper hygiene and sanitary conditions, as well as education. Vector-borne diseases can be prevented by control measures that kill the vector or prevent its contact with humans. Infection by a pathogen or the development of a pathogen within a host can be prevented by vaccination (National Institutes of Health, 2007).

Currently, with 2 billion people travelling annually by air, an epidemic outbreak in one part of the world is only a few hours away from anywhere else. The WHO and CDC have found that more than 100 infectious diseases caused by microbes that affect humans and other animals have recently increased or shown a tendency to grow, expanding their geographical range of action or their epidemic activity and severity (Roman, 2014).

The fragmentation of species' habitats because of human activities is the root cause of the increase in zoonotic diseases arising from species migration and intimate contact between humans and wild species (Muñoz, 2019). Economic activities are being given more weight than human life, the conservation of biological resources and animal welfare. We are facing exponential growth of the human population. This excess population must be fed. So we create intensive production systems that wear down and damage ecosystems. These keep reducing the planet's biodiversity, creating a vicious circle because we are running out of resources to survive (de Sherbinin, 2007). Intensive systems, poorly organized, have generated an increase in zoonotic diseases and the delivery of a poor quality and contaminated final product.

To try to control the diseases bred by intensive production there is perilous overuse of antibiotics, with resistant superbugs emerging. To increase production rates we ignore the welfare of animals, creating hyper-productive breeds at the cost of the extinction of others, generating losses that affect ecosystems (NAWAC, 2017). We fail to adopt and enforce the punitive laws, strict audits and public policies that would be needed to prevent abuse by these economic systems and to address these fundamental existential threats.

We have reached a point where we must take preventive measures to combat and correct what we now know harms us as a species and has generated a deterioration of our natural resources. The requisite interconnectivity, technology and expertise in multiple domains exists, but there is an urgent need to involve all sectors of society in their application. Measures must be comprehensive and supported by laws and policies that serve the health of all.

The One Health vision (Broom 2020; Fox 2020) needs to be adopted to make the population aware that we are all interconnected and that in producing a product we must take into account the consequences for the health of the entire planet, including nonhuman 
species. We must devise corrective measures that can be unified worldwide, because what affects one country will sooner or later affect even the most distant country. Global communication, support and sanctions are necessary. We have brough ourselves into a socioeconomic condition that has affected our mental and physical health, generating profound uncertainty about our own future and that of our loved ones. We must not forget that these consequences are the outcome, directly or indirectly, of human error. This pandemic has been a shock for all of us. We must now either correct this human error or succumb to it.

\section{References}

Broom, Donald M (2020) Brain complexity, sentience and welfare. Animal Sentience 29(27)

Chapman, Colin A. \& Huffman, Michael A. (2018) Why do we want to think humans are different? Animal Sentience 23(1)

De Sherbinin, A., Carr, D., Cassels, S., \& Jiang, L. (2007). Population and Environment. Annual Review of Environment and Resources, 32, 345-373.

FAO (2020) What is pollinator management?

Fox, Michael W. (2020) One planet, one health. Animal Sentience 30(6)

Jones KE, Patel NG, Levy MA, Storeygard A, Balk D, Gittleman JL, Daszak P. Global trends in emerging infectious diseases (2008). Nature 451 (7181): 990-3.

Muñoz C. del V., Patricia. (2019). A latent threat to humanity. Chilean Journal of Infectology, 36 (1), 7-8.

National Institutes of Health (USA) (2007) Understanding Emerging and Re-emerging Infectious Diseases.

NAWAC OPINION on animal welfare issues associated with selective breeding (2017).

Pievani, Telmo. (2014). The sixth mass extinction: Anthropocene and the human impact on biodiversity. Rendiconti Lincei. 25(1): 85-93.

Rodríguez Ferri, Elías F. (2013) "One Health". Collaboration is necessary. Annals of the Royal Academy of Doctors of Spain 17(1): 205-226

Román Casal, M. (2014). The threat to man from emerging microbes in a global world. Bulletin of the Royal Academy of Córdoba of Sciences, Fine Letters and Noble Arts 163, 115-150.

Steffen, W., Grinevald, J., Crutzen, P. \& J Mcneill, J. (2011). The Anthropocene: conceptual and historical perspectives. Phil. Trans. R. Soc. A 369, 842-867

Taylor LH, Latham SM, Woolhouse ME Risk factors for human disease emergence (2001). Philos Trans R Soc Lond B Biol Sci. 356 (1411): 983-9

Wiebers, David and Feigin, Valery (2020) What the COVID-19 crisis is telling humanity. Animal Sentience 30(1)

Ziman, John (2003) Science and civil society. Isegoría, No 28 (2003). 